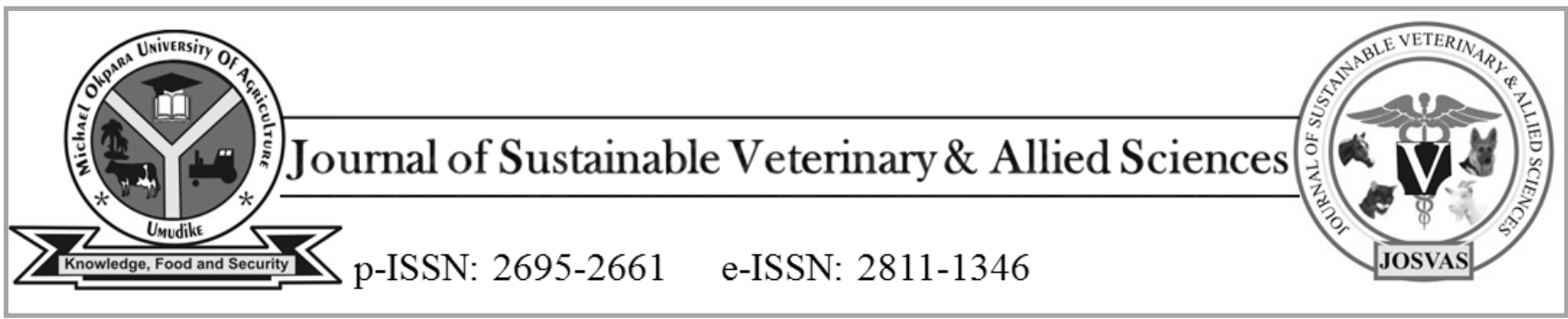

UJoVAS 2021, Vol 1, Issue 1: 15-19

C2021 College of Veterinary Medicine,

Michael Okpara University of Agriculture, Umudike, Nigeria

Original Research Article

\title{
Heavy metal residues in offals, muscle and eggs of intensively reared poultry birds in Umuahia, Abia State \\ ${ }^{1 *}$ Kalu, E., ${ }^{1}$ Akporube, K.A. \& ${ }^{2}$ Ukpai, N. O. O. \\ ${ }^{l}$ Department of Veterinary Public Health and Preventive Medicine, Michael Okpara University of Agriculture, Umudike, ${ }^{2}$ Bioresource Development Center, National Biotechnology Development Agency, Federal Ministry of Science and Technology, Isanlu, Kogi State, Nigeria.
}

*Corresponding author: kalu.ekenma@ mouau.edu.ng

\begin{abstract}
Poultry meat and poultry products have gradually become delicacy in Nigeria and are used in most celebrations for entertainment. Therefore there is the need for constant monitoring to ensure they are wholesome and suitable for human consumption. The aim of this study was to determine the presence and concentrations of Manganese (Mn), Zinc (Zn) and Iron $(\mathrm{Fe})$ in the thigh muscle and offals (kidney, liver and gizzard) of both broilers and layers reared under intensive system of management using an Atomic Absorption Spectrophotometer (AAS). In both broilers and layers, all meat and offal samples had concentrations of Mn and Fe that were above the maximum permissible levels (MPL) stipulated by FAO/WHO. In layers, the concentrations of $\mathrm{Mn}(5.276 \pm 0.023 \mathrm{mg} / \mathrm{kg})$ and $\mathrm{Fe}(7.067 \pm 0.569 \mathrm{mg} / \mathrm{kg})$ were highest in the liver. The concentration of $\mathrm{Zn}(5.039 \pm 0.009 \mathrm{mg} / \mathrm{kg})$ was found to be highest in the kidney. In broilers, Mn $(5.105 \pm 0.053 \mathrm{mg} / \mathrm{kg})$ accumulated more in the thigh muscle than any other organ whereas the highest concentration of $\mathrm{Fe}(6.256 \pm 0.246 \mathrm{mg} / \mathrm{kg})$ was found in the liver. The mean concentration of $\mathrm{Mn}, \mathrm{Zn}$ and Fe in eggs was $5.081 \pm 0.033,5.092 \pm 0.021$ and $7.102 \pm 0.146(\mathrm{mg} / \mathrm{kg})$ respectively. The concentration on $\mathrm{Mn}$ in eggs was slightly above the maximum residual limits of $5.0 \mathrm{mg} / \mathrm{kg}$. The high mean concentrations of $\mathrm{Mn}$ and $\mathrm{Fe}$ found in the study are of great public health concern because these metals are bioaccumulative and with continuous consumption, may pose a serious threat to public health.
\end{abstract}

Keywords: Broilers, eggs, heavy metals, layers, offals, thigh muscles.

\section{INTRODUCTION}

Poultry is a valuable food source rich in many essential nutrients that include protein, minerals, vitamins and fat (Schonfeldt \& Gibson, 2008). In Nigeria, the poultry industry is widely accepted by most societies mainly because of its meat which is an excellent source of protein. Also the little capital, labour and land involved in starting up the poultry business has led to its tremendous growth as a business venture of more than $5 \%$ per annum when compared to $3 \%$ for pig and $1.5 \%$ for cattle. Due to the increasing demand for meat and eggs, several adjustments have been made as regards poultry productions and poultry products (Abanikannda et al., 2007, FAO, 2006, Power \& Dick, 2000). The intensive poultry farming is seen as a way to quickly increase the supply of an economical, palatable and healthy food protein for growing urban populations (Sparks, 2006), while the industry provides employment opportunity for millions of people who are directly involved in poultry production as well as associated supply chains.

The increase in consumption of poultry and subsequent high demand have also led to an improvement in both food production and processing technology which in turn has increased the chances of contamination of food with various environmental pollutants, especially heavy metals. Ingestion of these contaminants by animals causes deposition of residues in meat (Sabir et al., 2003).

The main sources of heavy metals in poultry birds are contaminated poultry feeds and water. The poultry feed is often contaminated with heavy metal through the various raw materials used for its production. These heavy metals can be bioaccumulative (Iwegbue et al., 2008; Munoz-olives 
\& Camara, 2001) and this results in toxicity in human with serious adverse effect on mental and central nervous system as well as damage to blood composition, as well as the kidneys, lungs, and liver, and reduces energy levels. Longterm exposure may result in slow progressive physical, muscular and neurological degeneration that mimic Alzheimer's disease, Parkinson's disease, muscular dystrophy and multiple sclerosis (Amirah et al., 2013).

Heavy metal toxicity has been proven to be one of the major threats to human health (Zeng-Yei, 2004) and even at very low concentrations, the presence of some of these heavy metals in foodstuffs can cause serious health problems such as central nervous disorders, anemia, damage to the kidneys and bones, cancer, glucosuria, osteomalacia, increased allergic reaction and genetic mutation (Capark \& Katalenic, 2001; Monisha et al., 2014; Manju, 2015). Heavy metals like iron, copper, zinc and manganese are essential and they play an important role in biological system but may have an adverse effect if included in the diet at excessively high concentration (Munoz-olives \& Camara, 2001; Okoye et al., 2011). Once in the body, heavy metals are distributed among tissues or excreted (Burger et al., 2002; Massanyi et al., 2003).

Eggs from poultry are important source of nutrients, containing all of proteins, lipids, vitamins and minerals. Eggs can be used as evidence for environmental pollution since they can accumulate the heavy metals from diet and the surrounding environment (Ahmed et al., 2017). Fresh chicken eggs are included in several food products for different functions (Sharkawy \& Ahmed 2002, Leggli, 2010) and should be monitored along with the muscles and offals for heavy metal contamination.

The continuous consumption of contaminated poultry products by humans could be of great public health concern in the nearest future. Therefore, this study was designed and carried out to determine the concentrations of some heavy metals ( $\mathrm{Mn}, \mathrm{Zn}$ and $\mathrm{Fe}$ ) in poultry reared under intensive management system.

\section{MATERIALS AND METHODS}

\section{STUDY AREA}

The study was carried out in Umuahia. Umuahia is the capital city of Abia state and it is made up of Umuahia North and Umuahia South Local Government areas. These Local Governments are also composed of clans such as Umuopara, Ibeku, Olokoro, Ubakala and Ohuhu (Figure I). Umuahia is located at longitude $5035^{\prime} \mathrm{N}$ and latitude $7025^{\prime} \mathrm{E}$, at an altitude of 122 meters above sea level, it has a total land area of $600 \mathrm{~km}^{2}$.

\section{SAMPLE PREPARATION FOR WET DIGESTION}

Ten different poultry farms within Umuahia town were used for this study. In each poultry farm, five live birds were obtained and taken to the laboratory where they were dissected to harvest their offals (Liver, gizzard and kidney) and thigh muscles which were used to determine the presence of heavy metals in them. In farms where birds had started laying, egg samples were collected and processed accordingly. The offals and thigh muscles were initially washed using distilled water. Each sample was oven-dried at $65^{\circ} \mathrm{C}$ for 48 hours and later homogenized with aid of pestle and mortar. 2 grams of each homogenized sample was used for wet digestion. The heavy metals ( $\mathrm{Mn}, \mathrm{Zn}$ and $\mathrm{Fe}$ ) in the samples were determined according to the analytical techniques earlier described by Belton (2006).

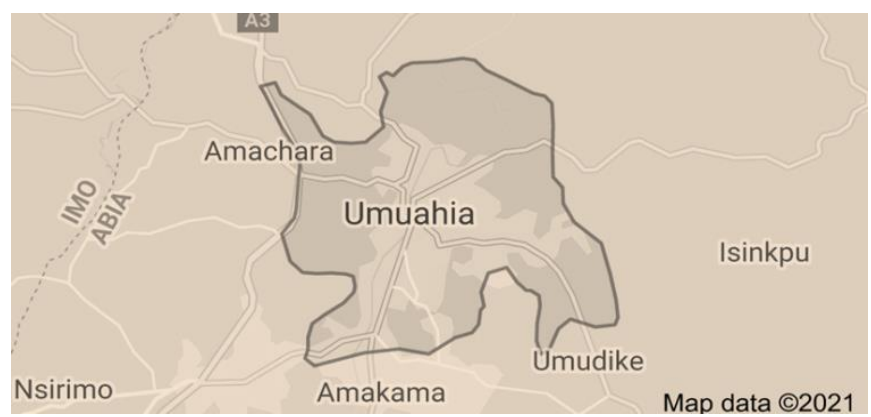

Figure I: Map of Study area

\section{SAMPLE DIGESTION AND HEAVY METAL ANALYSIS FOR MUSCLE AND OFFALS}

$2 \mathrm{~g}$ of each homogenized sample was mixed with $5 \mathrm{mls}$ concentrated Nitric Acid $\left(\mathrm{HNO}_{3}\right), 2.5 \mathrm{mls}$ Hydrogen Peroxide $\left(\mathrm{H}_{2} \mathrm{O}_{2}\right)$ and $2.5 \mathrm{mls}$ Perchloric Acid $\left(\mathrm{HClO}_{4}\right)$ and left to stand undisturbed overnight in a sample digestion block. The pre-digested samples were heated step by step up to a final temperature at $120^{\circ} \mathrm{C}$ for complete digestion until the solution became clean, colourless and crystal clear (Alonso et al., 2000). This procedure was repeated for solutions that were not crystal clear until they became clear. The crystal clear solution was then transferred into a $25 \mathrm{ml}$ volumetric flask and the flask was then filled up to the $25 \mathrm{mls}$ mark with distilled de-ionized water. The digested samples were then filtered and stored in a nitric acid prewashed polyethylene bottle for heavy metal analysis (Stahr 1991; Tessier et al., 1999).

The concentrations of $\mathrm{Mn}, \mathrm{Zn}$ and Fe were determined using a Model 200 Atomic Absorption Spectrophotometer (AAS) manufactured by Buck Scientific (Norwalk, Connecticut). This was done in accordance with the instructions on the manual.

\section{SAMPLE PREPARATION, DIGESTION AND HEAVY METAL ANALYSIS FOR EGGS}

The blunt side of each egg was cut using sterilized pointed forceps and dissecting scissors. The albumen and yolks were placed in a glass jar. Samples were dried at $75^{\circ} \mathrm{C}$ until constant weight was obtained and then subjected to wet digestion for further analysis. 2 grams of the sample was 
placed in a digestion tube and pre-digested in $10 \mathrm{ml}$ concentrated $\mathrm{HNO}_{3}$ at $135^{\circ} \mathrm{C}$ until the liquor was colourless. $10 \mathrm{ml}$ of $\mathrm{HNO}_{3}, 1 \mathrm{ml}$ of $\mathrm{HClO}_{4}$ and $2 \mathrm{ml}$ of $\mathrm{H}_{2} \mathrm{O}_{2}$ were added to the mixture and heated at $135^{\circ} \mathrm{C}$ for 1 hour or until the mixture became colourless. The resultant product was then allowed to evaporate slowly to near dryness. $1 \mathrm{ml} \mathrm{HNO}_{3}$ was added to the dried digest and subsequently filtered and diluted to $25 \mathrm{ml}$ with $1 \mathrm{ml} \mathrm{HNO}_{3}$. Buck Scientific Atomic Absorption Spectrophotometer (AAS) was then used for detecting the presence and concentrations of heavy metals in the solutions using a standard method described by Association of Analytical Chemists (AOAC) in 2000.

\section{STATISTICAL ANALYSIS}

The data on the different variables obtained from the study was analyzed statistically using IBM SPSS version 20.0 computer program (SPSS Inco. Chicago, II, USA).Analysis of Variance and Post Hoc test (Fisher's Least Significant Difference) were performed to find out the statistical difference among mean levels of $\mathrm{Mn}, \mathrm{Zn}$ and Fe present in the offals, muscles and eggs at $\mathrm{P} \leq 0.05$. Microsoft Excel (Microsoft Corporation, Redmond, WA, USA) was used for graphical presentation of data.

\section{RESULTS}

The levels of heavy metals in broilers were presented in Table I. The mean concentration of $\mathrm{Mn}$ in gizzard, kidney, liver and thigh muscles were $5.100 \pm 0.010,5.049 \pm 0.047$, $5.066 \pm 0.016$ and $5.105 \pm 0.053$ respectively. These values were all greater than the maximum residual limit of $0.5 \mathrm{mg} / \mathrm{kg}$. The highest concentration was seen in thigh muscle while the lowest was observed in the kidney.

The concentrations of $\mathrm{Zn}$ in gizzard, kidney, liver were $4.990 \pm 0.012,5.018 \pm 0.040$ and $4.979 \pm 0.048 \mathrm{mg} / \mathrm{Kg}$ respectively. The concentration of $\mathrm{Zn}$ in thigh muscle was $4.995 \pm 0.016 \mathrm{mg} / \mathrm{Kg}$. The $\mathrm{Zn}$ levels in all these organs were below the maximum permissible level prescribed by WHO/FAO.

Iron $(\mathrm{Fe})$ in all samples exceeded the recommended daily intake of $0.8 \mathrm{mg} / \mathrm{kg}$. The highest concentration of $\mathrm{Fe}(6.256 \pm$ $0.246)$ was seen in the liver and the lowest $(5.667 \pm 0.252)$ was observed in the thigh muscle (Table 1). The difference in concentration of $\mathrm{Fe}$ in the offals and thigh muscles was not statistically significant $(\mathrm{p}=0.782)$.

The mean concentrations of $\mathrm{Mn}(5.276 \pm 0.023)$ and $\mathrm{Fe}$ $(7.067 \pm 0.569)$ were highest in the liver of the sampled layers (Table II). The mean concentration of Mn was lowest in the thigh muscle $(4.987 \pm 0.008)$ while Fe was lowest in the kidney (6.140 \pm $0.072)$. The mean concentration of $\mathrm{Zn}$ was found to be highest in the kidney $(5.039 \pm$ $0.009)$ and lowest in the gizzard $(5.013 \pm$ 0.010).The difference in the mean concentrations of $\mathrm{Mn}$ in the gizzard, liver and thigh muscle was significantly $(\mathrm{P} \leq 0.05)$ different from one another, while those of $\mathrm{Zn}$ and Fe were not significantly different

The mean concentrations of $\mathrm{Mn}$ and $\mathrm{Fe}$ in meat and offal samples from layer birds were above the maximum permissible levels (MPL) stipulated by WHO and FAO (2010, 2000).The concentrations of $\mathrm{Zn}$ were all below MPL of $20 \mathrm{mg} / \mathrm{kg}$ established by the codex Alimentarius (Codex, 1995).

The concentration of Mn was slightly above the MPL of $5.0 \mathrm{mg} / \mathrm{kg}$ set by while the concentrations of $\mathrm{Zn}$ and $\mathrm{Fe}$ in the egg sampled were below the MPL of $20 \mathrm{mg} / \mathrm{kg}$ and $44 \mathrm{mg} / \mathrm{kg}$ set by FAO/WHO $(2010,2000)$ respectively (Table III).

\section{DISCUSSION}

The overall results revealed that different concentrations of heavy metals were present in the edible offals, thigh muscle and eggs obtained from poultry farms within Umuahia town, Abia State Nigeria. The $\mathrm{Zn}$ levels in the offals, thigh muscles and eggs were within the maximum permissible level.

On the contrary, the levels of $\mathrm{Mn}$ and Fe in all the samples were higher than the maximum permissible level The three heavy metals, $\mathrm{Zn}, \mathrm{Mn}$ and $\mathrm{Fe}$ investigated in the present study are considered as essential dietary micro-nutrients for poultry and play important roles in various physiological processed. For instance, $\mathrm{Zn}$ is associated with optimal immune function, fast wound healing and maintenance of skin integrity. Manganese has been linked with blood clothing while $\mathrm{Fe}$ is important for haemopoesis (Prashanth et al., 2015). However, all mineral elements, be it essential or potentially toxic, can have an adverse food effect upon the humans and animals if their inclusion in the diet is exceedingly beyond the maximum permissible level.

The high concentrations of $\mathrm{Mn}$ and $\mathrm{Fe}$ in the offals of both broiler and layers may be indicative of the fact that the feed and/or environment are contaminated. Excess heavy metals can impair important biochemical process posing a threat to human health, plant growth and animal life (Ikenaka et al., 2010). The liver of both layers and broilers accumulated high levels of Mn and this agrees with the work by Ogbomida et al., 2018 who also reported high levels of Mn above MPL in both liver and muscles of poultry and cattle. The high accumulation of $\mathrm{Fe}$ in the thigh muscles is quite rare as heavy metals tend to accumulate more in the liver and kidney (WHO, 2007, Demirezen \& Uruc, 2006, Behnaz et

Table I: Mean concentration ( $\mathrm{mg} / \mathrm{kg})$ of heavy metals in broilers

\begin{tabular}{lllll}
\hline \multirow{2}{*}{$\begin{array}{l}\text { Heavy } \\
\text { metals }\end{array}$} & Gizzard & Kidney & Liver & Thigh muscle \\
\cline { 2 - 5 } $\mathrm{Mn}$ & $5.100 \pm 0.010$ & $5.049 \pm 0.047$ & $5.066 \pm 0.016$ & $5.105 \pm 0.053$ \\
$\mathrm{Zn}$ & $4.990 \pm 0.012$ & $5.018 \pm 0.040$ & $4.979 \pm 0.048$ & $4.995 \pm 0.016$ \\
$\mathrm{Fe}$ & $6.237 \pm 0.498$ & $5.965 \pm 0.068$ & $6.256 \pm 0.246$ & $5.667 \pm 0.252$ \\
\hline
\end{tabular}


Table II: Mean concentration $(\mathrm{mg} / \mathrm{kg})$ of heavy metals in layers $(\mathrm{n}=25)$

\begin{tabular}{|c|c|c|c|c|c|c|}
\hline \multirow{3}{*}{$\begin{array}{l}\text { Heavy } \\
\text { Metals }\end{array}$} & \multicolumn{6}{|c|}{ Mean \pm SEM $(\mathrm{mg} / \mathrm{Kg})$} \\
\hline & & & & Thigh & $\mathrm{P}$ & MPL \\
\hline & Gizzard & Kidney & Liver & Muscle & Value & $(\mathrm{mg} / \mathrm{kg}$ \\
\hline $\mathrm{Mn}$ & $5.150 \pm 0.005$ & $5.134 \pm 0.060$ & $5.276 \pm 0.023$ & $5.044 \pm 0.053$ & 0.021 & $0.5 / 1.0$ \\
\hline $\mathrm{Zn}$ & $5.013 \pm 0.010$ & $5.039 \pm 0.009$ & $5.024 \pm 0.049$ & $4.987 \pm 0.008$ & 0.108 & 20.0 \\
\hline $\mathrm{Fe}$ & $6.920 \pm 0.416$ & $6.140 \pm 0.072$ & $7.067 \pm 0.569$ & $7.059 \pm 0.311$ & 0.321 & 0.8 \\
\hline
\end{tabular}

Table III: Mean concentration of heavy metals $(\mathrm{mg} / \mathrm{Kg})$ in sampled whole eggs from 5 farms

\begin{tabular}{lllcc}
\hline Heavy Metals & MPL $(\mathrm{mg} / \mathrm{Kg})$ & Mean \pm SEM & Min & Max \\
\hline $\mathrm{Mn}$ & $0.5-5.0$ & $5.081 \pm 0.033$ & 5.034 & 5.144 \\
& 20.0 & $5.092 \pm 0.021$ & 5.058 & 5.129 \\
$\mathrm{Fe}$ & 44.0 & $7.102 \pm 0.146$ & 6.813 & 7.278 \\
\hline
\end{tabular}

al., 2016). The accumulation of heavy metals was

are maintained are of upmost importance to avoid further contamination of the environment and by extension contamination of food from poultry origin meant for human consumption.

\section{CONFLICT OF INTEREST}

The authors have no conflict of interest to declare

unevenly

distributed in the various organs/tissues of the poultry birds and this can be attributed to the fact that accumulation of heavy metals in the various organs and tissues of the animals depends on the interval of exposure and the quantity ingested which is greatly influenced by the production and reproduction phase of the animals, as well as their age and breed, eating habits, growth and moulting (Kim et al., 2008; Baykov et al., 2003). The low concentration of $\mathrm{Zn}$ in this study could be due to its low concentrations in the soil and/or environment where grains used for feed production were grown (Behnaz et al., 2016).

In the sampled eggs, the concentration of $\mathrm{Mn}$ in this study was high when compared with that of Babu et al., 2018 who reported $0.401 \pm 0.026 \mathrm{mg} / \mathrm{kg}$. Eggs are highly nutritious and are considered to be economical when compared to other sources of protein (Surai \& Sparks, 2001; AL-Ashmawy, 2013) hence eggs are consumed by a lot of people from various income classes. They can become contaminated with heavy metals through agricultural activities, industrial waste and intake of contaminated feeds by the laying birds (Singh et al., 2007; Chowdhury et al., 2011; Abdulkhaliq et al., 2012). Contamination of the environment and dietary intake of contaminated meat and meat products from food chain has been the most common and principal pathways of human exposure to heavy metals (Mahmood et al., 2012).

\section{CONCLUSION}

The continuous consumption of the flesh, organs and eggs of poultry birds contaminated with heavy metals higher than those recommended by FAO/WHO is of high public health risk because it may lead to detrimental health challenges in the future. To reduce or minimize the concentrations of residues of heavy metals in poultry meat and its products, poultry feed and water quality should be monitored frequently to ensure that they are not contributing to the high heavy metals deposition in poultry meat and products. Also the environment where poultry farms are sited and how they

\section{REFERENCES}

Abanikanda, O.T.F., Olutogun, O., Leigh, A.O \& Ajayi, L.A. (2009). Statistical modelling of egg weight and egg dimensions in commercial layers. International Journal of Poultry, 6 (1), 59-63.

Abdulkhaliq, A., Swaileh, K.M., Hussein, R.M. \& Matani, M. (2012). Levels of metals $(\mathrm{Cd}, \mathrm{Pb}, \mathrm{Cu}$ and $\mathrm{Fe}$ ) in cow's milk, dairy products and hen's eggs from the West Bank, Palestine. International Food Research Journal, 19(3), 1089-1094.

Ahmed Abdel-Hameid Ahmed, Enas El-Prince Mohammed, Doha Yahia \&Al-Shimaa Mohamed Faried (2017). Lead, Cadmium and Copper Levels in Table Eggs. Journal of Advanced Veterinary Research, 7(3), 66-70

AL-Ashmawy \& M.A.M. (2013). Trace elements residues in the table eggs rolling in the Mansoura City markets Egypt. International Food Research Journal, 20(4), 1783-1787.

Alonso M.L., Benedito J.L., Miranda M., Castillo C.,

Hernandez J. \& Shore R.F. (2000). Arsenic, cadmium, lead, copper and zinc in cattle from Galicia, NW Spain. Science of Total Environment, 246, 237-248.

Amirah, M.N., Afiza, A.S., Faizal, W.I.W., Nurliyana, M.H., Laili, S. (2013). Human health risk assessment of metal contamination through consumption of fish. Journal of Environment Pollution and Human Health, 1 (1), 1-5.

AOAC (2000). Approved Method of American Association of Cereal Chemists. Assoc. Cereal chem. (10th). Inc. St. Paul. Minnesota, U.S.A.

Baykov B., Hristev H., Penkov, D., Zaharinov B., Georgieva Y., Wetstein W. \& Steinbach J. (2003). Movement of cadmium and lead in anthropogenically formed trophic chains of a pasture type. Journal Central European Agriculture, 4, 389.

Behnaz Bazargani-Gilani, Mohamadreza Pajohi-Alamoti, Aliasghar Bahari and Abas Ali Sari (2016). Heavy Metals

and Trace Elements in the Livers and Kidneys of

Slaughtered Cattle, Sheep and Goats, Iranian Journal of

Toxicology, 10(6), 7-13

Burger J., Gaies K., Lord C., Brisbin I., Shuka S. \& 
Gochfeld M. (2002). Metal levels in Raccoon tissues: Differences on and off the department of energy's Savannah River site in South Carolina. Environmental Monitoring and Assessment, 74, 67.

Capark, K. \& Katalenic M. (2001). Food contamination monitoring in Crootia. ARH. High Rada, 52(2), 169-75.

Chowdhury, M.Z., Siddique, A.A., Hossain, S.M.A., Kazi, A.I., Ahsan, A.A., Ahmed, S. \& Zaman, M.M. (2011). Determination of essential and toxic metals in meats, meat products and eggs by spectrophotometric method. Journal of Bangladesh Chemistry Society, 24(2), 165172.

Codex, 1995. Alimentarius Commission (CAC) Doc. no. CX/FAC 96/17. Joint FAO/WHO food standards programme. Codex general standard for contaminants and toxins in foods.

Demirezen O. \& Uruc K. (2006). Comparative study of trace elements in certain fish, meat and meat products. Food Chemistry, 32, 215-222.

FAO/WHO (2010). Summary Report of the Seventy-third Meeting of JECFA. Joint FAO/ WHO Expert Committee on Food Additives, Geneva.

FAO/WHO (2000). Report of the 32nd Session of the codex committee of the food additives Contaminants. Beijing People's Republic of China, 20-24 March.

FAO (2006). World agriculture: Towards 2030/2050 interim report. Rome.

Ikenaka, Y., Shouta, M. M. N., Kaampwe, M., Kennedy, C., Hiroki, T., Naoharu, M., \& Mayumi, I. (2010). Heavy metal contamination of soil and sediment in Zambia. Afr Journal of Environmental Science Technology, 4(11): 729-739.

Iwegbue, C., Nwajei, G., \& Iyoha, E. (2008). Heavy metal residues of chicken meat and gizzard aird turkey meat consumed in southern Nigeria. Bulgarian Journal of Veterinary Medicine, 11(4), 275 - 280

Kim, J. \& Koo T.H. (2008). Heavy metal distribution in chicks of two Heron species from Korea. Archives of Environmental Contamination \& Toxicology, 54, 740-747

Leggli, C.V.S., Bohrer, D., de Nascimento, P.C., de Carvalho, L.M. \& Garcia, S.C., (2010). Determination of sodium, potassium, calcium, magnesium, zinc and iron in emulsified egg samples by flame atomic absorption spectrometry. Talanta Journal, 80, 1282-1286.

Mahmood, Q., Rashid, A., Ahmad S.S., Azim, M.R. and Bilal, M. (2012).Current status of toxic metals addition to environment and its consequences. In: Anjum et al., editors. The Plant Family Brassicaceae: Contribution Towards Phytoremediation, Environmental Pollution.

Manju M. (2015). Effects of Heavy Metals on Human Health, Social Issues and Environmental Problems. September, 2015

Massanyi P., Tataruch F., Slameka J., Toman R. and Jurik R. (2003). Accumulation of lead and cadmium and mercury in liver and kidney of Brawn Hare in relation to the season, age and sex in the West Slovakian Lowland. Journal Environmental Sciences and Health, 38, 1299.

Monisha J., Tenzin T., Naresh A., Blessy B.M.,

Krishnamurthy N. B. (2014). Toxicity, mechanism and health effects of some heavy metals, Interdisciplinary Toxicology, 7(2), 60-72.
Munoz -Olives R., \& Camara C. (2001). Speciation related to human health, In L. Ebdon, L. Pitts, R. Cornelis, H. Crews, O. F. Donard, P. Quevauviller. Trace element speciation for environment food and health. The Royal Society of Chemistry, 331-353.

Ogbomida E.1.T., Shouta M.M.N., Nesta Bortey-Sam, Balazs O., Isioma T., Alex A. E., Ogbeide O., Martins O. A. , Iriagbonse P.F., Lawrence I.E., Hazuki M., Yoshinori I. \& Mayumi I. (2018). Accumulation patterns and risk assessment of metals and metalloid in muscle and offal of free-range chickens, cattle and goat in Benin City, Nigeria. Ecotoxicology and Environmental Safety, 151, 98-108

Okoye C.O.B, Ibeto C.N. \& Ihedioha J.N (2011). Assessment of heavy metals in chicken feeds sold in south eastern, Nigeria. Advances in Applied Science Research, 2(3), 63-68

Power, J.F. \& Dick, W.A. (2000). Land Application of Agricultural, Industrial, and Municipal By- products. Soil Science Society of America Inc., Madison, WI.

Prashanth, L., Kattapagari, K.K., Chitturi, R.T., Baddam, V.R. \& Prasad, L.K. (2015) A review on role of essential trace elements in health and disease. J NTR University Health Science, 4, 75-85

Sabir, S.M., Khan, S.W. \& Hayat, I. (2003). Effect of environmental pollution on quality of meat in district Bagh, Azad Kashmir. Pakistan Journal of Nutrition, 2(2), 98-101.

Sharkawy, A.A. Abdou, K.H.A \& Manal S.H. (2002): Estimation of some metallic pollutants in different poultry tissues. Assuit Veterinary Medical Journal, 48(95), 65- 74

Sparks, N.H.C (2006). The hen's egg — its role in human nutrition changing? Worlds Poultry Science Journal, 62, 308-15.

Stahr, H.M. (1991). Arsenic, copper, iron, lead, thallium, and zinc in biological matrices and feed: atomic absorption spectroscopy. In: Analytical Method Toxicology. ed. Stahr HM, pp. 69-73. John Wiley and Sons Inc., New York, NY.

Surai, P.F. \& Sparks, N.H.C. (2001). Designer egg: from improvement of egg composition to functional food. Trends Food Science and Technology, 12: 7-16.

Singh, R.K., Chavan, S.L. \& Sapkale, P.H. (2007). Heavy metal concentrations in water, sediments and body tissues of red worm (Tubifex spp.) collected from natural habitats in Mumbai, India. Environmental Monitoring and Assessment, 129, 471-81.

Schonfeldt, H.C. \& Gibson N. (2008). Changes in the nutrient quality of meat in an obesity context. Meat Science, 80, 20-27.

Tessier, A, Campbell P.G.C. \& Bisson, M. (1999).

Sequential extraction procedure for the speciations of particular trace metals. Analytical Chemistry, 51, 844-851.

WHO (2007). Health risks of heavy metals from long-range transboundary air pollution. World Health Organization 2007. WHO Regional Office for Europe Copenhagen, Denmark (ISBN 978928907179 6).

Zeng-Yei H. (2004). Evaluating heavy metal contents in nine 
composts using four digestion methods. Bioresource

Technology, 95, 53-59. 